\title{
DGKZ wt Allele
}

National Cancer Institute

\section{Source}

National Cancer Institute. DGKZ wt Allele. NCI Thesaurus. Code C150101.

Human DGKZ wild-type allele is located in the vicinity of $11 \mathrm{p} 11.2$ and is approximately 48 $\mathrm{kb}$ in length. This allele, which encodes diacylglycerol kinase zeta protein, plays a role in the modulation of second messenger signaling. 